\title{
TINGKAT INKLUSI KEUANGAN SEKTOR PERBANKAN PADA MASYARAKAT DI KECAMATAN TELUK SEGARA KOTA BENGKULU
}

\author{
Jansen Lionardo \\ Dewi Rahmawati \\ Program Studi Manajemen, Fakultas Ekonomi dan Bisnis \\ Universitas Bengkulu
}

\begin{abstract}
This Study aims to analyze how the financial inclusion levels of people in the District Teluk Segara Bengkulu City. This study used questionnaires distributed a total of 300 questionnaires and only 288 questionnaires that can be used. The data analysis method is descriptive statistics. Financial inclusion level of respondens was low. The results showed the level of financial inclusions community in District Teluk Segara Bengkulu City, throught indicator of financial inclusions, banking penetration and use of banking service. The questionnaires of this study use OECD/INFE Toolkit For Measuring Financial Literacy and Financial Inclusions 2015.
\end{abstract}

Keyword: Financial Inclusions, Society in District Teluk Segara Bengkulu City.

\section{PENDAHULUAN}

Pemerintah bersama 0JK dan Bank Indonesia merasa inklusi keuangan sangat penting dalam rangka mengentaskan kemiskinan, menerbitkan Strategi Nasional Keuangan Inklusif (SNKI) yang memberikan arah bagi upaya perluasan akses layanan keuangan bagi masyarakat. SNKI yang diluncurkan pada Juni 2012 dan disempurnakan Juni 2013 terdiri dari enam pilar, yaitu:

1. Edukasi keuangan,

2. Fasilitas keuangan publik

3. Pemetaan informasi keuangan,

4.Kebijakan atau peraturan pendukung,

5. Fasilitas intermediasi dan distribusi, dan

6. Perlindungan konsumen.

Inklusi keuangan diciptakan untuk mengurangi angka kemiskinan dengan memberikan kesempatan bagi masyarakat untuk memberikan akses sistem 
keuangan (Chairudin, 2015). Dengan masih rendahnya tingkat inklusi keuangan, maka Indonesia masih tetap memiliki banyak masyarakat yang miskin. Rendahnya tingkat inklusi keuangan di Indonesia disebabkan kurang gencarnya bank dalam memperkenalkan produk keuangan sehingga banyak orang yang tidak tahu ataupun yang tidak mau karena tidak mengerti. Fenomena inilah yang menyebabkan produk keuangan hanya digunakan kalangan tertentu saja.

Program inklusi keuangan memiliki tujuan utama yaitu mendorong pertumbuhan inklusif melalui penurunan angka kemiskinan, peningkatan pembangunan atau pemerataan distribusi keuangan, serta peningkatan stabilitas sistem keuangan. Beberapa penelitian sudah membuktikan hal itu, seperti salah satunya penelitian dari Sarma dan Pais (2011). Dengan menggunakan metode OLS menyatakan bahwa tingkat pembangunan manusia dan inklusi keuangan memiliki hubungan positif untuk beberapa negara di dunia, selain itu Levine (1997) juga menyatakan terdapat hubungan positif antara fungsi sistem keuangan dengan pertumbuhan ekonomi dalam jangka panjang. Penelitian mengenai dampak inklusi keuangan terhadap kemiskinan dilakukan oleh Dixit dan Ghost (2013) dimana penyedia akses layanan keuangan memiliki potensi untuk mengeluarkan masyarakat miskin dari lingkaran setan kemiskinan melalui budaya menabung, penghematan dan memungkinkan untuk terciptanya pembayaran yang efisien dan rendah biaya. Sanjaya (2014) menggunakan model regresi serta metode data panel untuk mengestimasi hubungan inklusi keuangan dan kemiskinan di Indonesia mendapatkan hasil dimana inklusi keuangan melalui kredit mikro dapat meningkatkan status sosial maupun status ekonomi dari masyarakat miskin.Masih rendahnya tingkat inklusi keuangan di Indonesia (Global Findex, 2015), menunjukkan bahwa penlitian tentang inklusi keuangan di Indonesia harus dilakukan. Masih sedikitnya penelitian tentang inklusi keuangan di Indonesia membuat penulis tertarik untuk meneliti tingkat inklusi keuangan di salah satu Kecamatan di salah satu Provinsi di Indonesia. Pada penelitian ini, penulis mencoba menganalisis tingkat inklusi keuangan pada masyarakat di Kecamatan Teluk Segara Kota Bengkulu. Hal ini disebabkan terbatasnya kemampuan penulis untuk meneliti daerah lain yang jauh dari tempat tinggal penulis.

\section{METODE PENELITIAN}

\section{Jenis Penelitian}

Jenis penelitian yang digunakan yaitu penelitian deskriptif. Metode penelitian deskriptif merupakan metode yang digunakan oleh penulis untuk menemukan variabel penting yang berkaitan dengan masalah. Metode penelitian deskriptif juga digunakan untuk menganalisis data dengan cara mendeskripsikan atau menggambarkan data yang telah terkumpul 
sebagaimana adanya tanpa bermaksud membuat kesimpulan yang berlaku untuk umum atau genralisasi (Sugiyono, 2011; 147). Metode Penelitian tersebut digunakan untuk mengetahui gambaran inklusi keuangan masyarakat di Kecamatan Teluk Segara Kota Bengkulu.

Populasi, Sampel dan Teknik Pengambilan Sampel-Populasi dalam penelitian ini adalah masyarakat di Kecamatan Teluk Segara Kota Bengkulu yang berjumlah 25.765 orang. Sampel yang digunakan dalam penelitian ini adalah Masyarakat Kecamatan Teluk Segara golongan yang telah memiliki penghasilan sendiri. Metode dalam pengambilan sampel adalah menggunakan tekhnik non probability sampling dan purposive sampling. Martono $(2010 ; 78)$ non probability sampling merupakan tekhnik sampling yang tidak memberikan peluang atau kesempatan yang sama bagi setiap unsur atau anggota populasi untuk dipilih menjadi sampel, sedangkan porpusive sampling merupakan tekhnik penentuan sampel dengan pertimbangan tertentu.

Penulis akan memberikan kuisioner kepada masyarakat Kecamatan Teluk Segara Kota Bengkulu sesuai dengan persyaratan sampel (responden) yang diperlukan, karena tidak semua masyarakat di kecamatan Teluk Segara dapat dijadikan sampel penelitian ini. Pengambilan sampel dengan metode ini bertujuan untuk mendapatkan sampel yang representatif sesuai dengan kriteria yang ditentukan. Kriteria responden adalah kepala rumah tangga atau orang yang telah memiliki penghasilan sendiri di Kecamatan tersebut, hal ini bertujuan agar data penelitian ini memiliki beragam jawaban dari responden. Jumlah responden yang akan diberikan kuisioner adalah 5\% dari jumlah KK pada setiap Kelurahan di Kecamatan Teluk Segara Kota Bengkulu. Jumlah KK pada Kecamatan Teluk Segara Kota Bengkulu adalah 5.997 KK, sehingga jumlah responden yang akan diteliti adalah 5\% dari 5.997 yaitu 300 orang.

Penulis telah melakukan survey di Kecamatan tersebut. Dari 21 orang yang secara acak ditanyakan tentang inklusi keuangan, 12 orang menggunakan jasa keuangan di bank, 3 orang menggunakan jasa keuangan di koperasi, dan 6 orang tidak menggunakan jasa keuangan, dengan alasan tidak mengerti tata cara menggunakan layanan jasa keuangan dan sulitnya akses menggunakan layanan jasa keuangan terutama di bank yang memiliki persyaratanpersyaratan yang menyulitkan beberapa pihak terutama pihak-pihak menengah ke bawah.

Metode Pengumpulan Data-Metode pengumpulan data yang digunakan dalam penelitian ini adalah dengan cara penulis menyebarkan kuisioner yang 
berisikan pernyataan-pernyataan mengenai inklusi keuangan kepada masyarakat di Kecamatan Teluk Segara Kota Bengkulu. Sumber kuisioner, berdasarkan OECD/INFE Toolkit For Measuring Financial Literacy and Financial Inclusion 2015. Penggunaan Kuisioner akan membuat pernyataan dalam penelitian dan jawaban responden dapat dikemukakan secara tertulis, tekhnik ini memberikan tanggung jawab kepada responden untuk membaca dan menjawab pernyataan (Indirantoro dan Supomo, 2002; 154).

Metode Analisis Data- Metode analisis data yang digunakan dalam penelitian ini, adalah metode statistik deskriptif. Analisis statistik deskriptif bertujuan untuk menjelaskan tentang gambaran yang diteliti melalui data sampel tanpa melakukan analisis dan membuat kesimpulan yang berlaku umum. Analisis ini digunakan untuk menganalisis tingkat inklusi keuangan pada masyarakat di Kecamatan Teluk Segara Kota Bengkulu.

Penelitian ini ingin melihat bagaimana inklusi keuangan masyarakat di Kecamatan Teluk Segara Kota Bengkulu. Langkah pertama dalam penelitian ini melihat bagaimana karakteristik masyarakat di Kecamatan Teluk Segara Kota Bengkulu, yaitu: Usia, Jenis Kelamin, Status Pernikahan, pendidikan, pekerjaan, dan pendapatan per bulan. Karakteristik dianalisis dengan menggunakan analisis deskriptif dengan pendekatan distribusi frekuensi.

Hasil rata-rata setiap variabel akan diukur berdasarka Indeks of Financial Inclussions yaitu:

1. $0,5 \leq \mathrm{IFI} \leq 1$ high financial inclusions

2. $0,3 \leq \mathrm{IFI} \leq 0,5$ medium financial inclusion

3. $0,0 \leq \mathrm{IFI} \leq 0,3$ low financial inclusion

\section{HASIL PENELITIAN DAN PEMBAHASAN}

Gambaran Umum Eleven Cafe-Objek penelitian ini adalah masyarakat di Kecamatan Teluk Segara Kota Bengkulu golongan menengah ke atas dan memiliki penghasilan sendiri yang dapat melakukan manajemen keuangan pribadi. Berdasarkan objek penelitian tersebut, tingkat inklusi keuangan masyarakat Kecamatan Teluk Segara Kota Bengkulu dapat digambarkan. Kota Bengkulu merupakan ibukota Provinsi Bengkulu yang terbentuk 
berdasarkan Undang-Undang darurat Nomor 6 tahun 1956 tentang pembentukan daerah otonom Kabupaten-kabupaten dalam lingkungan daerah Provinsi Sumatera Selatan.

Karakteristik Responden-Populasi dalam penelitian ini adalah masyarakat di Kecamatan Teluk Segara Kota Bengkulu. Teknik pengambilan sampel yang digunakan adalah purposive sampling sebanyak 5\% dari jumlah KK di Kecamatan tersebut yaitu 300 orang. Sampel tersebut terdiri dari masyarakat di Kecamatan Teluk Segara Kota Bengkulu golongan menengah ke atas yang telah bekerja ataupun memiliki penghasilan sendiri.Karakteristik responden yang menjadi sampel dalam penelitian ini adalah dilihat dari demografi responden yang meliputi jenis kelamin, usia, status pernikahan, pendidikan terakhir, pekerjaan, dan pendapatan perbulan. Bagian selanjutnya adalah menganalisis tingkat inklusi keuangan masyarakat di Kecamatan Teluk Segara Kota Bengkulu.

Karakteristik Responden Berdasarkan Jenis Kelamin-Dari 288 responden yang menjadi sampel dalam penelitian ini, maka tingkat proporsi pria lebih banyak jika dibandingkan dengan responden berjenis kelamin wanita. Maka, dapat dirinci bahwa persentase responden yang berjenis kelamin pria sebesar $63,5 \%$ sedangkan responden berjenis kelamin wanita sebesar 36,5\% sehingga dapat disimpulkan bahwa sebagian besar responden dalam penelitian adalah berjenis kelamin pria. Responden pria lebih banyak, dikarenakan banyaknya pria merupakan kepala keluarga yang bekerja dan memiliki penghasilan. Hal ini menunjukkan bahwa penduduk pria yang memiliki penghasilan lebih banyak daripada penduduk berjenis kelamin wanita yang memiliki penghasilan.

Karakteristik Responden Berdasarkan Usia Responden-Rata-rata responden dari masyrakat kecamatan Teluk Segara Kota Bengkulu yaitu berusia 35 tahun sampai dengan 45 tahun, yaitu sebanyak 107 responden. Biasanya, penduduk pada usia 25 tahun sampai dengan 35 tahun merupakan umur produktif seseorang yang sudah menunjukkan tingkat kemapanan untuk merencanakan keuangan. Hal ini menunjukkan bahwa penduduk Kecamatan teluk segara berdasarkan responden yang diteliti, merupakan masyarakat yang sudah melewati umur produktif seseorang.

Karakteristik Responden Berdasarkan Status Pernikahan-Responden yang sudah menikah lebih banyak daripada yang belum menikah, yaitu 272 orang responden sudah menikah dan hanya 16 orang responden belum menikah. Biasanya pada masa lajang, seseorang bisa menabung 
penghasilan mereka lebih banyak karena kebutuhan mereka lebih sedikit dibandingkan setelah menikah. Hal ini menunjukkan bahwa masyarakat di Kecamatan Teluk Segara sudah memiliki tanggungan hidup yang banyak sehingga mengurangi keinginan untuk menggunakan produk perbankan.

\section{Karakteristik Responden Berdasarkan Tingkat Pendidikan Responden-Tingkat pendidikan paling tinggi di Kecamatan Teluk Segara berdasarkan responden yang diteliti merupakan Sarjana dengan jumlah 119 orang atau $41,3 \%$ dari total responden. Sedangkan paling rendah adalah tingkat SMA yaitu 74 orang atau 25,7\%. Hal ini menunjukkan bahwa masyarakat Kecamatan teluk segara sudah memiliki kemampuan yang lebih baik dalam mengatur keuangan mereka.}

Karakteristik Responden Berdasarkan Pekerjaan Responden-Dapat dilihat dari 288 responden, 83 orang wiraswasta, 40 orang pegawai negeri, 31 orang guru, 31 orang polisi, 66 orang nelayan, dan lain-lain 37 orang. Pekerjaan lain-lain ini antara lain: karyawan, pekerja kasar, pengangguran, dan pekerjaan lainnya yang tidak tertulis dalam pilihan kuisioner. Beberapa pekerjaan menuntut seseorang memiliki rekening di bank untuk mempermudah transaksi baik dalam proses jual beli, transfer gaji, maupun transfer bonus.

Karakteristik Responden Berdasarkan Tingkat Penghasilan Responden-Tingkat penghasilan masyarakat Kecamatan Teluk Segara yang paling tinggi berada pada tingkat 1.000.000-2.500.000 yaitu 121 orang atau $42 \%$ dari jumlah responden. Sedangkan tingkat penghasilan paling rendah adalah masayrakat dengan pendapatan $>10.000 .000$ yaitu hanya 17 orang atau 5,9\% dari responden yang diteliti. Hal ini menunjukkan bahwa masyarakat Kecamatan Teluk Segara akan sulit untuk menggunakan produk-produk perbankan karena penghasilan yang hanya cukup untuk biaya sehari-hari.responden betah untuk berlama-lama di cafe.

Deskripsi Responden Berdasarkan Kepemilikan Tabungan di BankSebanyak 204 dari 288 responden memiliki tabungan di bank. Hal ini menunjukkan bahwa kepemilikan tabungan di bank pada kecamatan Teluk Segara cukup tinggi yaitu 70,8\%. Berdasarkan IFI yang ditemukan oleh M. Sarma (2012), dapat disimpulkan bahwa penggunaan tabungan di Kecamatan Teluk Segara sangat tinggi. Dalam penelitian ini, 84 responden tidak menggunakan tabungan di bank dikarenakan penghasilan yang paspasan, potongan-potongan di bank seperti mengambil uang di atm lain, potongan bulanan dan lain-lain, prosedur di bank yang mewajibkan nasabah mendepositkan uang mereka dalam jumlah tertentu, dan ada juga yang beralasan kurangnya pengetahuan. 
Deskripsi Responden Berdasarkan Produk Perbankan Yang DikenaliDari 287 responden dari 288 responden mengenal produk perbankan. Hal ini menunjukkan bahwa responden yang tidak memiliki rekening di Bank mengenali beberapa produk perbankan. Dari tabel 4.4 responden yang memilik rekening di Bank hanya 204 orang. Namun, di tabel 4.5 menunjukkan bahwa 287 responden mengenal produk perbankan yaitu Kartu Debit (ATM). Produk perbankan yang paling banyak di kenali yaitu Kartu Debit (ATM) dengan 287 reponden, sedangkan produk perbankan yang paling sedikit dikenali adalah Reksadana dengan 84 atau hanya $29,2 \%$. Berdasarkan tabel di atas dapat dilihat bahwa total rata-rata dari jawaban responden sebesar $60,31 \%$ yang artinya pengetahuan responden mengenai produk perbankan tinggi menurut IFI.

\section{Deskripsi Responden Berdasarkan Sumber Informasi Produk} Perbankan-Dari 288 reponden, 159 responden mengenal produk perbankan melalui iklan di TV, radio, dan internet, 245 responden mengenal produk melalui sales-sales, 199 responden mengenal melalui teman yang menggunakan produk, dan 2 responden tidak memiliki informasi. Sumber informasi yang paling banyak digunakan responden untuk mengenal produk perbankan adalah melalui sales-sales yaitu 245 responden yaitu $85,1 \%$ dari total semua responden.

Menurut responden, sales-sales merupakan sumber informasi yang lebih baik dalam memperkenalkan produk perbankan. Hal ini dikarenakan salessales dapat ditanyakan secara langsung mengenai produk-produk perbankan yang akan digunakan dan sales-sales juga bisa membantu memberi informasi bila dikemudian hari ada masalah pada produk yang digunakan. Dengan kata lain, responden merasa aman karena memiliki seseorang yang bertanggung jawab atas keputusan mereka dalam menggunakan produk perbankan.

Selain sales-sales, teman yang menggunakan produk merupakan alasan responden menggunakan produk perbankan ada beraneka ragam. Seperti mempermudah transaksi mereka dalam bisnis, ikut-ikut teman, gengsi, dan ada juga yang mengatakan bahwa bila produk yang saya pakai bermasalah setidaknya saya punya teman untuk masalah itu.

Untuk responden yang memilih iklan di TV, radio dan internet mereka memiliki alasan bahwa mereka lebih bebas untuk mengenal produk terutama melalui internet. Karena beberapa responden merasa malu untuk bertanya langsung ke bank atau sales-sales mengenai produk perbankan.

Deskripsi Responden Berdasarkan Produk Perbankan Yang Pernah Digunakan-Dari 288 responden hanya 212 responden yang pernah menggunakan produk keuangan. Produk perbankan yang paling banyak digunakan responden adalah Kartu debit (ATM) dan tabungan dengan 212 
responden. Produk perbankan yang paling sedikit digunakan adalah reksadana yaitu hanya 11 orang atau hanya 5,2\%.

Tabungan dan kartu debit merupakan produk yang paling banyak digunakan responden karena tabungan merupakan produk dasar yang harus dimiliki nasabah untuk dapat terakses ke produk-produk perbankan lainnya. Sedangkan kartu debit/ATM akan di dapat oleh nasabah bila memiliki rekening di bank. Untuk reksadana masih sedikit yang menggunakan dikarenakan kurangnya informasi mengenai produk tersebut sehingga nasabah merasa enggan menggunakannya, selain itu beberapa nasabah merasa lebih baik uang yang mereka gunakan untuk reksadana mereka gunakan untuk pengembangan usaha mereka.

\section{Deskripsi Responden Berdasarkan Produk Perbankan Yang} Digunakan Dalam 2 Tahun Terakhir-Dari 288 responden hanya 204 responden yang masih menggunakan produk perbankan. Dari tabel dapat disimpulkan bahwa reksadana adalah produk perbankan yang paling jarang digunakan. Sedangkan kartu debit (ATM) dan tabungan merupakan produk perbankan yang paling banyak digunakan yaitu 204 responden. Selain itu terdapat 84 orang yang sudah tidak menggunakan produk perbankan.

Dalam hal ini, tabungan dan kartu debit/ATM masih merupakan produk yang paling banyak digunakan karena merupakan akses awal untuk terhubung pada produk-produk perbankan lain. Terjadi penurunan pada produk yang masih digunakan yaitu dari 212 responden yang menggunakan produk perbankan, menjadi 204 responden. Hal ini dikarenakan beberapa responden tidak menggunakan lagi produk perbankan tersebut karena merasa produk perbankan kurang berguna untuk mereka, potonganpotongan yang dirasakan cukup berat bagi responden dan juga sulitnya akses seperti ATM dengan jenis bank yang mereka miliki.

Total dari produk perbankan yang masih digunakan adalah 273,5\%. Sehingga dari 10 produk diperoleh rata-rata total sebesar $27,35 \%$. Bedasarkan IFI tingkat inklusi penduduk berdasarkan 288 responden yang diteliti adalah rendah karena di bawah $30 \%$.

Deskripsi Responden Berdasarkan Alasan Menggunakan Produk Perbankan-Dari 288 responden, 173 responden menggunakan produk perbankan karena dianggap mempermudah transaksi, 19 responden mengharapkan keuntungan dari bank, dan 96 orang responden tidak memiliki alasan menggunakan produk perbankan. 96 responden yang menjawab tidak tahu, terdiri dari 84 orang responden yang sudah tidak menggunakan produk perbankan dan 12 orang lainnya memiliki alasan lain menggunakan produk perbankan selain alasan yang terdapat dalam pilihan kuisioner.

Mempermudah transaksi merupakan alasan yang paling banyak dijawab oleh responden dikarenakan menurut responden dengan memiliki rekening 
di bank mereka bisa melakukan kerjasama bisnis dengan orang yang berbeda daerah dengan mereka tanpa harus saling bertemu, transfer gaji mereka sehingga tidak repot antri untuk mengambil gaji, transfer bantuanbantuan negara, dan tidak perlu membawa uang cash terlalu banyak sehingga jauh dari tindakan kriminal.

Pembahasan-Secara umum penelitian ini menunjukkan hasil yang cukup memuaskan. Hasil analisis deskriptif yang melibatkan responden sebanyak 288 orang, menunjukkan bahwa masyarakat di Kecamatan Teluk Segara Kota Bengkulu yang menggunakan rekening di bank sudah tinggi. Hal ini dapat dilihat dari data yang diperoleh yaitu dari 288 responden yang diteliti, 204 responden menggunakan rekening di bank. Menurut Sarma (2008), inklusi keuangan merupakan sebuah proses yang menjamin seluruh lapisan masyarakat dalam hal ketesediaan, penggunaan, dan kemudahan akses terhadap layanan keuangan formal.

Berdasarkan Indeks of Financial Inclusions (IFI), tingkat penetrasi perbankan di Kecamatan Teluk Segara berdasarkan kepemilikan rekening di Bank adalah tinggi yaitu 70,8\%. Selain itu, untuk tingkat penetrasi perbankan di Kecamatan Teluk Segara Berdasarkan Produk perbankan yang diketahui adalah tinggi yaitu $60,31 \%$.

Berdasarkan survey langsung yang dilakukan penulis, jumlah ATM dan Bank yang tersebar di Kecamatan Teluk Segara masih sedikit. Jumlah ATM dan Bank paling banyak tersebar terdapat di Kelurahan Pintu Batu yaitu 15 ATM dan jumlah dan 7 Bank/Cabang. Masih banyak kelurahan yang belum memiliki akses ATM dan Bank/Cabang. Jumlah keseluruhan ATM dan Bank/Cabang di Kecamatan Teluk Segara adalah 24 ATM dan 8 Bank/Cabang. Hal ini menunjukkan bahwa ketersediaan layanan jasa keuangan di Kecamatan Teluk Segara masih cukup rendah.

Penggunaan jasa perbankan juga merupakan salah satu dimensi yang digunakan untuk mengukur tingkat inklusi keuangan. Penggunaan jasa perbankan meliputi produk perbankan yang pernah digunakan, produk perbankan yang masih digunakan, dan alasan seseorang menggunakan produk perbankan. Berdasarkan data yang diperoleh, penggunaan jasa perbankan masyarakat Kecamatan Teluk Segara Kota Bengkulu masih tergolong rendah untuk beberapa produk perbankan. Hal ini disebabkan kurangnya informasi untuk beberapa produk-produk perbankan sehingga masyarakat masih ragu untuk menggunakan produk-produk tersebut. Faktor lain yang menyebabkan rendahnya penggunaan jasa perbankan yaitu sulitnya akses masyarakat menengah kebawah untuk menggunakan beberapa produk perbankan dan adanya lembaga keuangan lain selain bank yang memiliki produk yang sama dengan produk-produk di bank. 
Berdasarkan data yang diperoleh, tingkat penggunaan jasa perbankan masyarakat Kecamatan Teluk Segara menurut produk perbankan yang pernah digunakan adalah menengah yaitu $32,91 \%$ sedangkan menurut produk perbankan yang masih digunakan adalah rendah yaitu $27,34 \%$. Hal ini menunjukkan masih perlunya banyak sosialisasi produk-produk perbankan kepada masyarakat di Kecamatan Teluk Segara karena tingkat penggunaan jasa perbankan yang masih rendah.

Tanggapan yang diberikan responden mengenai kepemilikan rekening di bank diperoleh persentase 70,8\% responden memiliki rekening di bank, artinya tingkat kepemilikan rekening di Bank secara umum cukup tinggi. Tanggapan responden untuk pengetahuan mengenai produk-produk perbankan yang dikenali cukup tinggi dengan rata-rata 60,31\%. Produk yang paling banyak dikenali adalah tabungan dan kartu debit (ATM) yaitu 288 orang. Sedangkan produk yang paling sedikit dikenali oleh responden adalah reksadana yaitu hanya $29,2 \%$ dan tabungan pensiun yaitu hanya $30,9 \%$.

Tanggapan responden mengenai sumber informasi produk perbankan diperoleh persentase $55,2 \%$ melalui iklan, $85,1 \%$ melalui sales-sales, $69,1 \%$ melalui teman yang menggunakan produk, dan $0,7 \%$ menjawab tidah tahu. Menurut pendapat beberapa responden, sales-sales dan teman yang menggunakan produk merupakan sumber informasi yang paling banyak mereka gunakan karena mereka dapat bertanya secara langsung mengenai produk-produk perbankan secara detail dan langsung sehingga informasi menjadi sangat jelas.

Tanggapan responden mengenai produk perbankan yang pernah mereka gunakan diperoleh 212 responden dari 288 responden yang diteliti pernah menggunakan produk perbankan. Produk perbankan yang paling banyak digunakan adalah kartu debit (ATM) dan tabungan dengan persentase $100 \%$ dari responden yang pernah menggunakan rekening di bank. Hal ini dikarenakan kartu debit (ATM) merupakan syarat utama dalam pembuatan rekening di bank sebelum mengakses produk-produk perbankan lainnya. Untuk produk perbankan lain yang pernah digunakan tergolong sangat rendah karena tidak ada yang melebih 50\%. Faktor yang menyebabkan rendahnya penggunaan produk perbankan lainnya karena sulitnya akses untuk menggunakan produk-produk, adanya lembaga keuangan bukan bank yang memiliki produk yang sama dengan akses yang lebih mudah, kurangnya informasi mengenai produk-produk tersebut sehingga masyarakat ragu untuk menggunakannya, dan faktor ekonomi setiap individu masyarakat.

Tanggapan responden mengenai produk perbankan yang masih mereka gunakan diperoleh 204 responden dari 212 responden yang pernah 
menggunakan produk perbankan masih menggunakan produk-produk perbankan. Menurut responden yang sudah tidak menggunakan produk perbankan lagi, mereka tidak menggunakan produk perbankan lagi dikarenakan beratnya pajak bulanan, potongan saat transfer antar bank yang berbeda, kecilnya bunga yang diterima, dan merasa tidak mendapatkan manfaat saat menggunakan produk-produk perbankan tersebut.

Tanggapan responden mengenai alasan menggunakan produk perbankan diperoleh 173 responden menjawab mempermudah transaksi, 19 responden mengharapkan keuntungan dari bunga bank, dan 96 responden menjawab tidak tahu. Menurut beberapa responden yang menjawab tidak tahu, alasan mereka menggunakan produk perbankan karena ingin belajar menabung, ingin memiliki akses menggunakan produk perbankan lain, dan beberapa responden memang tidak pernah menggunakan produk perbankan sehingga mereka tidak tahu alasan menggunakan produk perbankan tersebut.

\section{KESIMPULAN}

Simpulan-Berdasarkan hasil penelitian dan pembahasan sebelumnya, kesimpulan yang didapat sebagai berikut:

1. Berbagai macam karakteristik responden yang digunakan untuk menggambarkan tingkat inklusi keuangan masyarakat di Kecamatan Teluk Segara Kota Bengkulu, inkluasi keuangan juga dapat dipengaruhi oleh faktor demografi dan sosial responden. Karakteristik responden berdasarkan jenis kelamin adalah sebagian besar responden berjenis kelamin laki-laki dengan umur 35 tahun sampai dengan 45 tahun yang kebanyakan dari mereka berada sudah dalam tahapan siklus finansial mereka, sehingga pada siklus ini mereka sudah memiliki uang. Sebagian besar responden memiliki pendidikan tinggi Sarjana dengan pekerjaan sebagai wiraswasta dengan pendapatan berkisar 1 juta sampai dengan 2,5 juta perbulan. Terlihat maka semakin tinggi pendidikan dan pendapatan seseorang, semakin besar tingkat inklusi keuangan seseorang.

2. Tanggapan responden mengenai produk perbankan yang dikenali bermacam-macam. Hal ini dipengaruhi oleh pengetahuan dan sumber informasi yang mereka miliki mengenai produk-produk perbankan yang ada.

3. Tingkat penggunaan produk perbankan yang pernah digunakan responden cukup rendah yaitu $32,9 \%$. Hal ini dikarenakan kurangnya pengetahuan masyarakat mengenai produk-produk perbankan yang ada dan sulitnya akses untuk menggunakan beberapa produk perbankan. Produk yang paling sedikit digunakan reksadana dan tabungan pensiun. Reksadana 
sedikit digunakan dikarenakan kurangnya informasi mengenai produk. Sedangkan tabungan pensiun sedikit digunakan dikarenakan masyarakat Bengkulu yang lebih suka menggunakan uang daripada menabung. Selain itu, masyarakat cenderung menggunakan tabungan pensiun dari lembaga keuangan lain.

4. Tingkat penggunaan produk perbankan yang masih digunakan masyarakat dalam 2 tahun terakhir sangat rendah dengan rata-rata 27,35\%. Produk yang paling sering digunakan adalah Tabungan dan kartu debit (ATM) yaitu $100 \%$. Sedangkan produk perbankan yang masih digunakan dalam 2 tahun terakhir lainnya sangat rendah. Hal ini dikarenakan masyarakat sudah memiliki modal sendiri untuk usahanya dalam 2 tahun terakhir, adanya lembaga keuangan bukan Bank, sulitnya akses menggunakan beberapa produk perbankan, rasa kecewa masyarakat terhadap beberapa produk perbankan yang pernah digunakan, dan kurangnya informasi mengenai produk-produk perbankan.

5. Alasan masyarakat menggunakan produk perbankan paling banyak yaitu mempermudah transaksi seperti transfer, isi pulsa, bayar listrik, dan pembayaran pembayaran lainnya. 33,3\% responden menjawab tidak tahu terdiri dari orang yang tidak menggunakan produk perbankan dan ada juga yang sekedar memiliki rekening bank tanpa alasan.

6. Alat penelitian (kuisioner) pada penelitian ini masih kurang sempurna. Masih banyak informasi yang belum terjangkau pada penelitian ini. Sehingga diharapkan peneliti selanjutnya dapat mengembangkan alat penelitian sehingga informasi yang di dapat bisa lebih baik.

7. Metode penelitian yang digunakan adalah metode deskriptif cukup baik untuk penelitian ini karena dapat menggambarkan tingkat inklusi keuangan dengan jelas.

Saran-Berdasarkan hasil kesimpulan yang telah dikemukakan dari penelitian, beberapa saran yang dapat diberikan adalah:

1. Tingkat inklusi keuangan masyarakat di Kecamatan Teluk Segara Kota Bengkulu tergolong tinggi mengenai kepemilikan tabungan di Bank, akan tetapi masih terdapat sebagian kecil masyarakat yang tidak mengerti tentang produk-produk perbankan sehingga banyak produk perbankan yang tidak bisa digunakan oleh masyarakat, maka dari itu inklusi keuangan masyarakat di Kecamatan Teluk Segara Kota Bengkulu perlu ditingkatkan lagi terutama pada pengetahuan mereka tentang produkproduk Bank.

2. Pihak Perbankan harus lebih gencar dalam memperkenalkan produkproduk mereka seperti cara penggunaan, manfaat, dan hal-hal lain yang perlu diketahui masyarakat sehingga masyarakat menjadi tertarik menggunkan produk-produk perbankan. Sehingga masyarakat tidak hanya sekedar mengetahui tentang produk perbankan, namun mereka juga bisa menggunakannya. 
3. Pihak perbankan harus lebih mempermudah akses masyarakat untuk menggunakan produk-produk perbankan yang ada sehingga masyarakat akan menggunakan produk yang ada dan bisa memperkenalkan produk tersebut ke masyarakat lainnya.

4. Masih rendahnya tingkat penggunaan produk perbankan dalam 2 tahun terakhir yaitu dengan rata-rata 27,35\% menunjukkan bahwa Otoritas Jasa Keuangan harus bisa menciptakan inovasi-inovasi program terbaru untuk meningkatkan tingkat inklusi keuangan. Salah satu contoh yang sudah dilakukan oleh Otoritas Jasa Keuangan adalah Agen Laku Pandai. OJK dapat membuat program lain yang serupa ataupun memperbaiki kualitas program yang sudah ada.

5. OJK juga dapat bekerja sama dengan pemerintahan setiap Provinsi dimana bantuan-bantuan provinsi kepada masyarakat-masyarakat terutama masyarakat kurang mampu disalurkan melalui bank-bank daerah di Provinsi-provinsi tersebut seperti yang sudah dilakukan di Jakarta pada era Gubernur Basuki Tjahja Purnama. Selain dapat meningkatkan tingkat inklusi keuangan, cara ini dapat membangun bank-bank daerah untuk dapat berkembang menjadi lebih baik.

6. Lembaga Keuangan harus lebih giat mensosialisasikan produk-produk keuangan seperti iklan, datang ke instansi seperti kelurahan, rt dan rw untuk menjelaskan mengenaik produk-produk keuangan sehingga masyarakat menjadi tertarik menggunakan produk-produk keuangan yang ada.

7. Peneliti selanjutnya diharapkan dapat mengembangkan alat penelitian seperti jumlah pertanyaan, penambahan variabel dan hal-hal lain yang penting sehingga informasi yang di dapat bisa lebih baik.

8. Peneliti selanjutnya diharapkan mampu mengembangkan metode penelitian seperti menggunakan cluster, dll sehingga penelitian bisa menjadi lebih baik.

\section{DAFTAR PUSTAKA}

Allen, F., Kunt, A. D., Klapper, L., and Peria, M. S. M. (2012). The Foundations of Financial Inclusion: Understanding Ownership and Use of Formal Accounts.

Andrianaivo, M., Kpodar, K. 2011. ICT, Financial Inclusion, and Growth: Evidence from African Countries. IMF Economic Review.

Atkinson, A. and F. Messy (2012), "Measuring Financial Literacy: Results of the OECD / International Network on Financial Education (INFE) Pilot Study", 
OECD Working Papers on Finance, Insurance and Private Pensions, No. 15, OECD Publishing.

Beck, T., Demirguc-Kunt, A., and Martinez Peria, M. S. (2007) Reaching out: Access to and use of banking services across countries.

Chakravarty, S.R., Pal, R. 2010. Measuring Financial Inclusion: An Axiomatic Approach. Indira Gandhi Institute of Development Research, Mumbai.

Garg, S. 2014. Financial Inclusion in India - a Review of Initiatives and Achievements. . JECRC University, Jaipur, Rajasthan, India

Global Findex tahun 2015

Halim, Abdul. 2005. Analisis Investasi. Jakarta: Salemba Empat.

Hannig, A., Jansen, S. 2010. Financial Inclusion and Financial Stability. A. Social Science Research Network.

http://www.definit.asia/penelitian-proyek14.html

http://www.bi.go.id/id/perbankan/keuanganinklusif/Indonesia/Contents/D efault.aspx

Indriantoro, Nur \& Sumpomo, Bambang. 2002. Metodologi Penelitian Bisnis. BPFE Yogyakarta; Yogyakarta.

Kamaludin dan Rini Indriani, 2012. Manajemen Keuangan "Konsep Dasar dan Penerapannya" Edisi Revisi, Penerbit CV. Mandar, Bandung.

Kempson, E. (2009), "Framework for the Development of Financial Literacy Baseline Surveys: A First International Comparative Analysis", OECD Working Papers on Finance, Insurance and Private Pensions, No. 1, OECD Publishing.

Khan. 2011. Financial inclusion and financial stability: are they two sides of the same coin?, Reserve Bank of India, Indian Bankers Association and Indian Overseas Bank, Chennai,

Laporan World Bank tahun 2008. www.worldbank.org

Laporan Bank Indonesia tahun 2011.www.bi.go.id.

Laporan Bappeda Bengkulu tahun 2014. Bappeda.bengkulukota.go.id

Morgan,P and Pontines,V. (2014). Financial Stability and Financial Inclusion. Asian Development Bank Institute Working Paper No. 448. Tokyo

Nassution, C.S. 2015. Financial Inclusion Policy : Developed vs Developing Countries. Badan Kebijakan Fiskal, Kementerian Keuangan.

Sarma, M. 2012. Index of Financial Inclusion - A measure of financial sector inclusiveness. University of Applied Science.

Sarma, M and Pais, J. (2011). Financial Inclusion and Development: A Cross Country Analysis.Journal of International Development 23

Sanjaya, I.M. (2014). Inklusi Keuangan dan Pertumbuhan Inklusif sebagai Strategi Pengentasan Kemiskinan di Indonesia. Bogor: Institut Pertanian Bogor.

Soetiono, K.S, 2014. Keuangan Inklusif. Otoritas Jasa Keuangan.

Sugiyono. 2004. Metode Penelitian Bisnis. Alfabeta, CV. Bandung

UU No. 21 tahun 2011 tentang Otoritas Jasa Keuangan. 